\title{
SIMULAATIO SOVELTUU MYÖS YRITYSKASVATUKSEEN
}

\author{
Kirjoittajaryhmä tarkastelee simulaatiota oppimisen- ja erityisesti \\ yrittäjyyden oppimisen - välineenä. Artikkeli pohjautuu eräisiin \\ yhdysvaltalaisiin asiasta tehtyihin tutkimuksiin sekä Tampereen yliopiston \\ jatko-opiskelija Hannu Salakarin tekemään lisensiaattityöhön \\ simulaattorikoulutuksen pedagogisen mallin kehittämisestä. Salakari \\ tekee parhaillaan väitöstyötä samasta aiheesta, Hän esitteli tutkimustu- \\ loksiaan pohjoismaiden aikuiskasvatuksen tutkijaseminaarissa Turun \\ yliopistossa 14.5.2005.
}

\section{OUTI HÄGG, AULI TOIVONEN, PEKKA HEINONEN JA JOUKO LÄÄKKÖ}

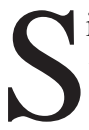

imulaatiota oppimisen välineenä on tutkittu tähän mennessä hyvin vähän, joten se on uutena tutkimuskohteena varsin kiehtova. Simulaattori (=jäljittelijä) keksittiin 1920-luvulla mittarilentokoulutuksen avuksi, jolloin ne olivat vielä varsin yksinkertaisia opetusvälineitä (=link-trainer). Näiden laitteiden tarkoituksena oli nopeuttaa mittarilentämisen oppimista turvallisesti ennen varsinaista lentokoulutusta. Ne toimivat siteenä (linkkinä) teorian ja käytännön välillä.

Teknisten innovaatioiden ja ratkaisujen myötä simulointi oppimisen välineenä on yleistynyt jatkuvasti (Honig 2004). Sitä käytetään jo apuna edellä mainitun lentokoulutuksen lisäksi kuormaautojen ajo-opetuksessa, metsäkoneiden käyttöopastuksessa, kirurgisessa leikkausharjoittelussa ja tavallisissa autokouluissa. Sen tarkoituksena on parantaa suorituksen laatua harjoittelu- tai koulutustilanteissa käytäntöä turvallisemmin ja halvemmin.

Patrickin (1992) mukaan taitojen oppimisessa simulaattoreilla voi olla huomattava merkitys. Simuloinnin etuja ovat muun muassa seuraavat asiat:

, todellisissa tilanteissa ei ole mahdollisuutta harjoitella

I virheet maksavat liian paljon ja niillä on koh tuuttomat seuraukset

simulointi säästää kustannuksia

simuloinnin avulla on mahdollista saada pa

lautetta

। simuloinnissa tehtävän suorittaminen ei aiheu ta stressiä
I mahdollisuus jakaa tehtävä simuloitaviin osiin (Keskinen 2002, 104-106.)

Artikkelimme taustalla on kysymys siitä, voidaanko simulaatiota käyttää myös yrittäjyyden opettamisessa. Aivan tuntematon simulointi ei ole yrittäjyyskasvatuksen piirissä. Australialainen professori Kevin Hindle (2002) toteaa, että yrittäjyyden opettaminen käytännössä on ongelmallista ja simulointi tarjoaa uudenlaisen mahdollisuuden toimia pedagogisesti tehokkaasti. Honig (2004) puolestaan arvioi, että vain harva simulaatiomalli on riittävän kehittynyt kuvatakseen riittävän realistisesti ympäröivää liike-elämää ja sen muutosta. Hindlen mukaan simuloinnin avulla on mahdollista tuottaa tehokkaasti kokemuksia esimerkiksi yrityksen kasvuvaiheesta, joka usein on muutoksessaan nopealiikkeistä. Ranskassa sijaitseva INSEADin yliopisto on tunnettu siitä, että siellä kehitetään ja käytetään simulointia opetusmenetelmänä muun muassa johtamisen, organisaatiokäyttäytymisen, rahoituksen ja markkinoinnin opetuksessa.

Käytännönläheiset opiskelusuunnitelmat, joihin sisältyy aitoja tai simuloituja elämänkokemuksia, rohkaisevat teoriaopetusta aktiivisemmin yrittäjyyteen (Honig, 2003). Högsdal (2004) on havainnut tutkimuksissaan, että simulaatioiden avulla päästään oppimaan paitsi teknisiä taitoja, myös sosiaalisia ja konseptuaalisia taitoja kuten yrittäjyyden ydin- ja metatason kykyjä. Parhaimmillaan opiskelija pääsee paitsi "tiedä miten” -osaamisen tasolle myös konstruktivistiselle "välitä miksi” tasolle. 
Shepherd puolestaan on tutkinut tapoja, joilla valmentaa yrittäjiä selviytymään yrityksen kriiseistä, ääritapauksessa konkurssista. Simulaatio on yksi hänen toimivista malleistaan. Shepherdin mukaan simulaation käytössä on tärkeätä opiskelijan aktiivinen osallistuminen. Sen avulla on mahdollista prosessoida osittain jopa tahdottomasti erilaisia tunnetiloja ja toimintastrategioita ongelmatilanteessa. Shepherd viittaa Petranekin ja Cooleyn tutkimuksiin, jonka mukaan simulaation käyttöä tehostaa ongelmatilanteeseen liittyvän, sanallisen selosteen kirjoittaminen. (Shepherd 2004, 280.)

\section{TEKEMÄLLÄ OPITAAN}

Simulointi tarkoittaa jonkin toiminnan jäljittelyä ja muistuttaa yksinkertaisessa muodossaan mentaaliharjoitusta. Simuloinnin keskeinen idea on tarjota harjoitteluympäristö, jossa kyseistä taitoa voidaan kehittää ilman suuria kustannuksia tai ilman riskiä. Simulointia on käytetty myös harjoiteltaessa vuorovaikutustaitoja. Käyttäytymisen simuloinnissa tuotetaan tilanteita, jotka tavallisesti tuottavat tietynlaisia tunteita tai ilmiöitä, joita halutaan tarkastella. (Keskinen 2002, 104-106.)

Hindlen ja Angehrnin tutkimukset osoittavat, että simulaatiomalleilla ja käytäntöön sidotuilla harjoitustehtävillä valmistetaan opiskelijoita kohtaamaan yrittäjyyden ennustamattomuus. Empatia ja kokeellinen oppiminen ovat osa simulaatiota. (Hindle \& Angehrn 1998). Simulaatioympäristö rohkaisee opiskelijaa kokeilemaan sekä samalla opettaa kohtaamaan virheet ja oppimaan niistä reaaliajassa. Shepherd painottaa artikkelissaan simulaation hyödyllisyyttä harjoiteltaessa tunteiden käyttöä. Simulaation avulla voidaan oppia näkemään tunteiden voima vaikeissa ongelmatilanteissa. Esimerkiksi kuinka ylikierroksilla toimiminen voi edesauttaa yrityksen joutumista vaikeuksiin. Shepherd esittää myös, kuinka simulaation avulla voidaan kehittää jokaiselle yrittäjälle tärkeätä tunneälyä. (Shepherd 2004, 284.)

Tyypillinen simulaatioperusteinen koulutus on tekemällä oppimista, jossa ollaan vuorovaikutuksessa järjestelmän kanssa. Opetuksen tarkoituksena on saada aikaan todellisia tiedollisia malleja, joilla oppiminen maksimoidaan. Opetukseen liittyy opastuksen lisäksi arviointikeskustelu, jossa reflektoidaan opetustilanne jälkikeskusteluna. Oppiminen tapahtuu kontekstuaalisen oppimismallin kautta, jossa koulutukseen otetaan todelli- sen ympäristön vaikutteita ja kasvaneet taidot siirretään tehostamaan koko oppimisprosessia. Simulaatiotutkimuksen tuloksena voidaan pitää pedagogista oppimismallia, jossa taitojen hankkimis- ja opetusprosessit ovat keskeisiä.

Salakari toteaa lisensiaattityössään Kannistoa (1986,174-175) siteeraten, että "hermeneuttisten tieteiden tehtävä ei ole vain tuottaa ja kerätä uusia tulkintoja, vaan pyrkimys on myös sovelluskelpoisten totuuksien löytämiseen”. Salakarin tutkimuksen aineistona on käytetty kirjallisuutta ja aikaisempia tutkimuksia. Kyseessä on kvalitatiivinen käsitteellis-teoreettinen tutkimus, jossa johdetaan uutta mallia induktiivisesti, yleistämällä aikaisemmista empiirisistä tutkimuksista (Järvinen \& Järvinen 2000, 15 -35). Käsitteellis- teoreettisissa tutkimuksissa pääpaino on käsitteissä ja teorioissa. Analyyttisessa vaiheessa kysytään "millä käsitteillä ja teorioilla muut tutkijat ovat tätä asiaa jäsentäneet”. Jos tutkimukseen kuuluu synteesivaihe, kysymys on "miten voisin konstruoida uuden käsitteen, mallin tai teorian, joka entistä paremmin tavoittaisi kyseessä olevasta asiasta tai ilmiöstä olennaisen” (Salakari 2004, 13; Järvinen \& Järvinen 2000, 10).

\section{PALAUTE MOTIVOI JA OHJAA TAVOITTEESEEN}

Simulaatiokoulutuksen analysointi tapahtuu osittain jo opetustapahtuman aikana aikaisemmin koulutukselle määriteltyjen tavoitteiden mukaisesti. Analysointi tapahtuu kontekstuaalisen analyysin kautta, jossa vertaillaan simulaattoria ja todellista ympäristöä keskenään. Simulaation oppimisprosessi on sosiaalinen oppimisprosessi, jossa on otettava huomioon myös simulaattorikoulutuksen eroavaisuudet todellisuuteen nähden. Debriefingissä tapahtuva jälkiarviointi on arvokas analysointitilanne, jossa reflektoinnilla on erittäin suuri merkitys asioiden käsitteellistämiseen ja koko oppimistapahtuman merkityksellisyyteen. Jälkiarvioinnissa analysoidaan simuloinnin erilaisuuksia ja samankaltaisuutta todellisuuden kanssa. Analysointi sisältää syvän sääntöjen, syiden ja johtopäätösten arvioinnin sekä tärkeiden asioiden erottelun vähemmän tärkeistä.

Hindle (2002) esittää esimerkin simuloinnin käytöstä yrittäjyyden opettamisesta ja tuo esiin konkreettisen listan tekijöistä, jotka tekivät simuloinnista tehokkaan yrittäjyyden opetusvälineen. 


\section{1) Epäuskon lykkääminen}

Hindlen (2002) tutkimuksessa on kysymys siis simulointipeliin osallistuvan valmiudesta "osallistua peliin”. Samaan on päätynyt Honig (2004), joka peräänkuuluttaa tässä yhteydessä uskottavuutta, relevanssia ja kattavuutta. Simuloinnissa opiskelija paneutuu rooliinsa niin syvällisesti, että se maksimoi oppimiskokemuksen. Hindle ehdottaakin, että 'epäuskon riittävä lykkääminen' on simuloinnissa keskeistä. Simuloinnissa on järjestäjän kyettävä vakuuttumaan siitä, että opiskelijat osallistuvat peliin innolla hyväksyen sen rajoitukset.

\section{2) Selkeä kommunikaatio}

Hindlen (2002) tutkimuksessa opiskelijat valittivat, että simuloinnissa harjoiteltava asia menetti uskottavuutensa. Simulointi oli epäonnistunut vakuuttamaan heidät 'epäuskon lykkäämisestä'. Syvällisempi selvitys toi ilmi, että epäilyksen lykkääminen oli perusta kyvylle luoda ja täyttää odotukset. Epäselvä kommunikaatio tuhoaa tämän kyvyn.

Tutkimustulos koostui seuraavista ominaisuuksista: järkevä opetustapa, opittavien asioiden merkityksellisyys, pelisäännöt ja toimintatavat, ohjelmaedellytykset, palaute, inhimilliset edellytykset, harjaantuneisuus, pelin rajoitukset, sopimus tavoitetasosta, arviointikriteerit ja koemenetelmät sekä ero pelipalautteen ja arvostelun välillä.

\section{3) Tekninen luotettavuus}

Jokainen pelin komponentti ja toteutuksen menettelytapa (ohjelmistot, laitteistot, dokumentointi, taidot, kokemukset ja järjestelijän pätevyys) kuvaavat teknistä luotettavuutta.

\section{4) Kustannus-hyöty -analyysi}

Kustannus-hyöty -analyysi on tärkeä, koska sen perusteella syntyy tai ei synny oikeutus valita simulointipeli muiden opetusmenetelmien sijasta. Tämä ei käsitä ainoastaan taloudellisia kuluja, vaan esimerkiksi investointia aikaan ja vaivannäköön suhteessa siihen hyötyyn, mitä opiskelijat saavat simulaatiosta. Jokaisen opettaja on arvioitava muuttuvia tekijöitä ympäristöolosuhteet huomioon ottaen.

\section{OPETA, NÄYTÄ JA HARJOITA}

Voidaan päätellä, että simulaatio-oppimisessa on perustana behavioristinen mallintaminen, joka on saanut laitteiden ja muun oheisopetuksen kehittyessä konstruktiivisia piirteitä ja lähestymistapaa. Simulaatiokoulutus on kehittynyt kokemusperustaiseksi koulutukseksi, jossa ennen koulutusta rakennetaan skenaariopohjainen malli, jossa määritellään oppimistavoitteet, tehtävät ja arviointiperusteet. Simulaatio lisää tutkimusten mukaan ongelmaratkaisukykyä ja -taitoja, automaatioiden ymmärtämistä, metakognitiivisia ja psykomotorisia taitoja sekä menetelmätuntemusta. Oppimisprosessien kautta simulaatiossa kehittyy oppijan kyky moniulotteiseen ja vuorovaikutteiseen ajatteluun, joita hän oppii itse tekemällä sekä palautteesta, jota hän saa harjoituksissa sekä simulaattorilta että opettajalta.

\section{KEINOTEKOISEN TILANTEEN AVULLA TODELLISIA KOKEMUKSIA}

Jalava et al. (2001) toteavat, että simulaatiossa luodaan keinotekoisen tilanteen avulla todellisia kokemuksia: tilanne on keinotekoinen, mutta tunteet ovat aitoja (Keskinen 2002, 106). Simulaatiooppimisen yhteydessä voidaan kysyä: kuinka paljon, milloin, miten ja millä tavoitteilla eri oppimistilanteissa on hyödyllistä simuloida suhteessa todelliseen toimintaan. Simulaattori voi heijastaa todellisuutta vain osittain, ei täydellisesti. Simulaatiotekniikka kuitenkin kehittyy jatkuvasti, jolloin tämäkin eroavaisuus pienenee lähes olemattomiin. Nämä aiheelliset kysymykset simulaation käytöstä oppimisvälineenä ovat mitä ilmeisimmin tilanne- ja tapauskohtaisia sekä aina asiayhteyteen liitettäviä harkinnanvaraisia pohdintoja. Yleisesti voi sanoa, että joissakin tilanteissa sekä turvallisuus- että kustannussyistä simulaattoria kannattaa käyttää opetuksessa niin paljon kuin mahdollista. Tietenkin myös oppimisen kattavuus ja vaikuttavuus pitää etukäteen arvioida. Tulevaisuudessa joudutaan pohtimaan yhä enemmän luottamusta simulaatio-opetusta kohtaan. Low, Venkataraman ja Srivatsan (1994) yrittivät kehittää simulaation, joka olisi samalla sekä pedagogisesti hyödyllinen että teoreettisen tutkimustyön salliva. Tutkijat havaitsivat näiden kahden tekijän olevan toisensa poissulkevia. Tarvitaan vielä paljon tutkimustyötä, jotta päästään 
simulaatioon, jossa voidaan mitata oppimisen laajuutta sekä sen vaikuttavuutta.

Joka tapauksessa simulaatioista tiedetään jo, että ne lisäävät oppimistilanteissa metakognitiivisia taitoja ja oppimisen siirtovaikutusta. Tulevaisuuden näkymät uusiksi oppimismalleiksi ovat, että simulaatioympäristöjä tullaan hyödyntämään yhä enemmän, mutta tutkimusta tältä oppimisalueelta tarvitaan lisää.

Mielenkiintoinen näkökulma yrittäjyyskasvatuksen simulaatioiden kannalta on ns. virtuaaliyhteisöjen käyttö. Larsen ja MacInerney ovat tutkineet, miten opiskelijoita valmennetaan erityyppisten virtuaaliyhteisöjen käyttöön. Tutkijoiden mukaan nämä ovat tulevaisuuden työyhteisöjä, joiden toimijoilla on oltava mm. riittävät kommunikointitaidot. (Larsen \& McInerney, 2002, 447) Tällainen yrittäjyyskasvatuksen tarpeista ja tavoitteista lähtevä simulaatio voisi toimia mainiona mallina yrittäjyyskasvatuksen alueella. Virtuaaliyhteisön simulaatioon voitaisiin sisällyttää työskentelytapoina mentorointi ja tutorointi. Globaalisuuden arkitodellisuutta tällaisessa virtuaaliyhteisössä voisi edustaa vaikkapa toisella puolella maapalloa asustava yrittäjämentori, joka on sitoutunut toimimaan simultaaniomallissa muiden tukena.

Tulevien simulaatioiden tulee keskittyä tuottamaan perinteisten analyyttisten yrittäjyystaitojen oppimisen rinnalla itseluottamuksen ja motivaation karttumista ja kasvanutta riskin- ja epävarmuudensietokykyä. Konvergentti ajattelu, jossa kaikki vaihtoehdot on valmiiksi syötetty tiedostoina simulaatioon, on unohdettava. On siirryttävä kohti divergenttiä mallia, jossa opiskelijat voivat omilla, ainutkertaisilla ratkaisuillaan vaikuttaa ja rakentaa simulaatiosta entistä paremman (Honig 2004.)

\section{LÄHTEET}

Hindle, K. (2002). A grounded theory for teaching entrepreneurship using simulation games. Journal of Simulation and Gaming, 33 (2), 236-241, Sage Publications.

Hindle, K. G., \& Angehrn, A. (1998). Crash Landing at INSEAD: initiating a grounded theory of the pedagogical effectiveness of simulation games for teaching aspects of entrepreneurship. Teoksessa S. Birley, Ed., 8th Annual Global Entrepreneurship Research Conference. Fontainebleau, Ranska: The
Wharton School, Imperial College.

Honig, B. (2003). Entrepreneurship Education: Toward a Model of Contingency-Based Business Planning. Wilfrid Laurier University and The University of Haifa. Academy of Management Learning and Education, 3 (3), 258-273.

Högsdal, N. (2003). Simulation and Gaming Approaches in Entrepreneurship-Education. Bonn: TERTIA Edusoft.

Järvinen, P. \& Järvinen, A. (2000). Tutkimustyön metodeista. Tampere: Opinpajan Kirja.

Kannisto, H. 1986. Ymmärtäminen, kritiikki ja hermeneutiikka. Teoksessa: Vuosisatamme filosofia. Niiniluoto I. \&Saarinen E. (EDS.), 145-243. WSOY.

Keskinen, E. (2002). Taidon oppiminen ja opettaminen. Teoksessa P. Niemi \& E. Keskinen (toim.) 2002. Taitavan toiminnan psykologia. Hakapaino Oy, 85-97.

Larsen, K.R.T. \& McInerney, C.R. Preparing to work in the virtual organization. Information \& management. 39, 445-456

Low, M., Venkataraman, S., \& Srivatsan, V. (1994). Developing an entrepreneurship game for teaching and research. Simulation and Gaming, 25. Sage Publications.

Salakari, H. (2004). Käytännön taitoja virtuaalisesti - simulaattoriopetuksen pedagogisen mallin kehittäminen. Lisensiaattityö. Ammattikasvatuksen tutkimus- ja koulutuskeskus. Tampereen yliopisto.

Salakari, H. (2005). Luentoesitys 14.5.2005: Simulaattorikoulutuksen pedagogisen mallin kehittäminen. Turun yliopisto.

Shepherd, D. (2004). Education Entrepreneurship Students About Emotion and Learning From Failure. University of Colorado at Boulder. Academy of Management Learning and Education, 3 (3), 274-287.

Artikkeli on kirjoittajaryhmän työ Tampereen yliopiston Ammattikasvatuksen tutkimus- ja koulutuskeskuksen yrittäjyyskasvatuksen syventävistä opinnoista. 